\title{
Museum Telekomunikasi Seluler Di Kota Surakarta
}

\author{
Papin Longaun Rosy, Mohammad Muqoffa, Samsudi \\ Program Studi Arsitektur \\ Universitas Sebelas Maret Surakarta \\ Email : papin.1r.93@gmail.com
}

\begin{abstract}
Nowadays cellular telecommunications has become one in our everyday activity. Cellular telecommunications is a method of communication over long distances using electromagnetic media that is divided into sections called cells. Issues underlying planning and design of the Cellular Telecommunications Museum in Surakarta, including the excessive use of cellular devices in Indonesia; high levels of cellular devices disposal that are not used but still feasible to use; indifference of society towards the use of cellular devices; the necessity for a place that act as information media for society and to take care the cellular devices; and the potentials of Surakarta as the museum site as seen from its history, economics, and social to cellular telecommunications. Design problem that arise from the existing issue is how to plan the museum as a place to storage, preservation, exhibitions, and educational for the cellular telecommunications technology in Surakarta. The objective of this design is to get the museum design as a place to storage, preservation, exhibitions, and educational for the cellular telecommunications technology in Surakarta. The result obtained is a museum design as a place to storage, preservation, exhibitions, and educational for the cellular telecommunications technology that can contribute on the use and maintenance of old mobile devices that are still feasible to use to the public through the focus of attracting public attention to visit the museum by the use of design aesthetic and arrangement of museum rooms which displays the features of cellular technology as a matter of museum collections, and also providing a place to supporting activities related to cellular technology.
\end{abstract}

Keyword: Cellular Device, Cellular Telecommunications. Exhibitions, Education, History, Preservation, Museum, Storage.

\section{PENDAHULUAN}

Dewasa ini telekomunikasi seluler telah menjadi keseharian kita, di mana sejak kemunculannya di dekade 1980-an, sekarang setidaknya telah menyentuh 6 miliar pengguna di seluruh dunia. Telekomunikasi seluler bekerja sebagai metode komunikasi jarak jauh dengan menggunakan media elektromagnetik yang dibagi dalam bagian-bagian yang disebut sel, dari sinilah teknologi ini dinamai.

Di Indonesia sendiri selama satu dekade terahir saja telah terdapat penambahan penggunaan perangkat seluler sebesar hampir 300 juta perangkat, dengan penambahan pertahun yang mencapai 31 juta perangkat per tahun $^{1}$, hal ini menunjukkan antusiasme masyarakat Indonesia yang sangat besar dalam penggunaan perangkat seluler.

Pemakaian yang sangat besar ini tetapi tidak diimbangi dengan pengolahan setelah

\footnotetext{
${ }^{1}$ http://data.un.org/Data.aspx?q=telephone $\& d=$ ITU\&f=ind 1 Code $\% 3$ aI 271
}

pemakaiannya, menurut statistik $^{2}$ rata-rata perangkat seluler diganti setiap 18 bulan dengan perbandingan rata-rata masa hidup sebuah perangkat hingga tujuh tahun, sekitar 70 persen dari perangkat seluler yang diganti itu didiamkan atau dibuang, 20 persennya dijual kembali, dan hanya 10 persennya didaur ulang, hal ini berarti dalam setahun lebih dari 27 juta perangkat di seluruh Indonesia akan menjadi barang tak berguna di mana setiap tahun angka ini akan semakin besar kecuali jika masyarakat dapat disadarkan untuk menghargai atau setidaknya peduli terhadap pemakaian perangkat seluler.

Masyarakat dapat disadarkan melalui sejarah seluler di mana dengan mengangkat sejarah perkembangan telekomunikasi seluler, perangkat yang sudah tidak terpakai dapat dilestarikan dengan menggandeng komunitas kolektor perangkat seluler yang sudah ada, di mana kolektor-kolektor ini dapat membantu

\footnotetext{
2 http://www.e-cycle.com/tag/mobile-phone-
} recycling-statistics/ 
dalam penggadaan dan juga perawatan perangkat seluler.

Menurut PP No.19 tahun 1995, museum merupakan pilihan yang tepat dalam rangka memperkenalkan masyarakat terhadap sejarah dan pentingnya teknologi seluler karena museum memiliki dua fungsi utama yaitu sebagai tempat pelestarian dan sumber informasi, kemudian dalam UU No.11 tahun 2010 sebagai dasar hukum tentang permuseuman, dapat disimpulkan bahwa dasar dari perencanaan museum ini adalah dalam rangka mewujudkan museum sebagai wadah penyimpanan, perawatan, pameran, dan pendidikan teknologi telekomunikasi seluler.

Perangkat seluler memiliki banyak bentuk dan dimensi, dengan bentuk yang paling umum adalah telepon genggam, terdapat banyak jenis dan model yang beredar sehingga peralatan seluler dibatasi pada peralatan seluler yang pernah atau sedang dipasarkan di Indonesia, atau perangkat yang bersifat pertama dalam jenisnya, selain itu terdapat koleksi tambahan yang berupa alat peraga, dokumentasi dan perangkat asing yang tidak digunakan di Indonesia, di mana dari semua itu diperlukan penanganan sendiri untuk menyimpan dan merawatnya dan pengkondisian yang tepat untuk pameran.

Kota Surakara menjadi fokus penempatan museum yang direncanakan dari pertimbangan bahwa Kota Surakarta sudah familiar dengan telekomunikasi seluler sejak awal diperkenalkan di Indonesia, Kota Surakarta juga telah menjadi pusat dari penjualan perangkat telekomunikasi seluler dan pusat dari pertemuan komunitas kolektor perangkat seluler di Jawa Tengah bahkan di Indonesia.

Museum yang direncanakan memiliki fokus sebagai wadah penyimpanan, perawatan, penyajian, dan pendidikan perkembangan teknologi telekomunikasi seluler yang dapat memberikan kontribusi tentang pemakaian dan pengolahan perangkat seluler yang tidak lagi digunakan secara luas tetapi masih layak pakai kepada masyarakat luas dengan cara menarik perhatian masyarakat untuk berkunjung ke museum melalui desain estetika dan penataan museum yang menampilkan fitur-fitur dari teknologi seluler sebagai materi koleksi museum, dan juga pemberian wadah kegiatan pendukung yang berhubungan dengan teknologi seluler. Di mana museum dikelola oleh lembaga pemerintah yang dibantu oleh komunitas lokal, lebih lanjut Museum Telekomunikasi Seluler merupakan ruang publik sehingga pemilihan, pengolahan tapak aksesibilitas dan juga peruangan harus diperhatikan.

\section{METODE}

Berdasarkan konsep perencanaan dan perancangan, museum yang direncanakan berfokus pada kegiatan penyimpanan, perawatan, pameran, dan pendidikan teknologi telekomunikasi seluler.

\subsection{Penentuan Kegiatan dan Peruangan}

Hal pertama yang dilakukan adalah penentuan kegiatan terutama kegiatan pengunjung museum yang berhubungan dengan pendidikan dilakukan di mana penentuan kegiatan ini bermuara pada hubungan dan besaran ruang, terdapat satu poin penting selama perhitungan kebutuhan ruang yang dilakukan yaitu pemberian ruang kosong tambahan untuk pengembangan jangka panjang museum.

\subsection{Penentuan Lokasi Tapak}

Setelah konsep kegiatan dan peruangan didapatkan, pemilihan tapak ditentukan dengan beberapa poin utama yaitu, antara lain aksesibilitas terutama dari pusat kota, dan luas dari analisis peruangan yang telah dilakukan.

\subsection{Penentuan Pencapaian ke Tapak}

Pencapaian pada tapak di bedakan menjadi dua yaitu pencapaian utama dan pencapaian samping, pada tahap ini ditentukan letak dari pencapaian tersebut.

\subsection{Penentuan Pemintakan (Zonasi)}

Selanjutnya pemintakan pada tahap ini ditetapkan penentuan pemintakan meliputi pemintakan secara horizontal dan vertikal sesuai dengan kebutuhan peruangan yang telah di lakukan pada tahap sebelumnya.

\subsection{Penentuan Bentuk dan Tampilan \\ Bangunan}

Tahap selanjutnya adalah penentuan tampak dan juga massa bangunan, didapati poin penting yaitu penggunaan unsur teknologi telekomunikasi seluler sebagai pembentuk massa dan tampak bangunan, penggunaannya dibatasi pada simbol-simbol yang digunakan pada teknik maupun teknologi seluler, bukan produk dari teknologi seluler sendiri. 


\subsection{Penyimpanan dan Pameran}

Pada tahap ini meliputi penentuan jumlah materi koleksi yang akan disimpan dan dipamerkan, jenis penyimpanan yang akan digunakan, periodisasi ruang pamer, teknis penyajian materi koleksi, dan perhitungan jarak pandang nyaman pada ruang pamer.

\subsection{Penentuan Sistem Bangunan}

Sistem bangunan yang terdiri dari struktur, utilitas dan estetika (bahan bangunan dan lansekap) ditentukan setelah semua parameter pada tahap sebelumnya didapat sehingga pelaksanaan perencanaan dan perancangan Museum Telekomunikasi Seluler di Kota Surakarta ini dapat memenuhi kriteria dan juga fokus yang telah ditentukan.

\section{ANALISIS}

\subsection{Analisis Peruangan}

Tabel 1.Kebutuhan Ruang Publik

\begin{tabular}{|c|l|l|}
\hline PELAKU & \multicolumn{1}{|c|}{ KEGIATAN } & PERUANGAN \\
\hline \multirow{5}{*}{$\begin{array}{c}\text { Pengunju } \\
\text { ng }\end{array}$} & Datang/pergi & Hall utama \\
\cline { 2 - 3 } & Parkir & Tempat parkir \\
\cline { 2 - 3 } & $\begin{array}{l}\text { Membeli tiket/ } \\
\text { informasi }\end{array}$ & Front desk \\
\cline { 2 - 3 } & Melihat koleksi & Ruang pamer \\
\cline { 2 - 3 } & Membaca buku & Perpustakaan \\
\cline { 2 - 3 } & Seminar/diskusi & R. seminar \\
\cline { 2 - 3 } & Praktek & R. workshop \\
\cline { 2 - 3 } & Melihat video & R. teater \\
\cline { 2 - 3 } & Istirahat & R. istirahat \\
\cline { 2 - 3 } & Metabolisme & KM/WC \\
\cline { 2 - 3 } & Sholat & Musholla \\
\cline { 2 - 3 } & Membeli suvenir & Retail \\
\cline { 2 - 3 } & $\begin{array}{l}\text { Bertamu ke } \\
\text { pengelolaan }\end{array}$ & Ruang tamu \\
\cline { 2 - 3 } & $\begin{array}{l}\text { Kegiatan } \\
\text { penunjang }\end{array}$ & $\begin{array}{l}\text { Ruang } \\
\text { serbaguna }\end{array}$ \\
\hline
\end{tabular}

Pada Tabel 1. terlihat kebutuhan peruangan yang mewadahi kegiatan pengunjung museum

Tabel 2. Kebutuhan Ruang Pengelola

\begin{tabular}{|c|c|c|}
\hline & & \\
\hline PELAKU & KEGIATAN & PERUANGAN \\
\hline Penoelola & Datang/pergi & Pintu samping \\
\hline 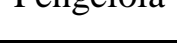 & Parkir & Tempat parkir \\
\hline
\end{tabular}

\begin{tabular}{|c|l|l|}
\hline \multirow{5}{*}{} & Bekerja & $\begin{array}{l}\text { Ruang } \\
\text { pengelolaan, } \\
\text { penyimpanan, } \\
\text { perawatan, } \\
\text { studi, dll }\end{array}$ \\
\cline { 2 - 3 } & Rapat & R. rapat \\
\cline { 2 - 3 } & Metabolisme & KM/WC \\
\cline { 2 - 3 } & Sholat & Musholla \\
\cline { 2 - 3 } & Makan & Kafetaria \\
\cline { 2 - 3 } & Menerima tamu & Ruang tamu \\
\cline { 2 - 3 } & $\begin{array}{l}\text { Kegiatan } \\
\text { penunjang }\end{array}$ & $\begin{array}{l}\text { Ruang } \\
\text { serbaguna }\end{array}$ \\
\hline \multirow{5}{*}{$\begin{array}{c}\text { Pihak } \\
\text { ketiga } \\
\text { (lembaga/ } \\
\text { sponsor) }\end{array}$} & Datang/pergi & Pintu samping \\
\cline { 2 - 3 } & Parkir & Tempat parkir \\
\cline { 2 - 3 } & Memberi materi & $\begin{array}{l}\text { Ruang } \\
\text { serbaguna, } \\
\text { seminar, } \\
\text { workshop }\end{array}$ \\
\cline { 2 - 3 } & Metabolisme & KM/WC \\
\cline { 2 - 3 } & Sholat & Musholla \\
\cline { 2 - 3 } & Makan & Kafetaria \\
\hline
\end{tabular}

Pada Tabel 2. terlihat kebutuhan peruangan yang mewadahi kegiatan pengunjung museum

\subsection{Analisis Tapak}

Penentuan lokasi museum didasarkan atas beberapa pertimbangan yang dapat mempengaruhi keberhasilan dari objek yang direncanakan.

1. Tujuan

Mendapatkan lokasi tapak museum yang sesuai dengan kebutuhan dan juga syarat pendirian museum

2. Dasar pertimbangan:

Berada pada wilayah pembagian pembangunan Kota Surakarta yang sesuai dengan RTRW Kota Surakarta yang berlaku, Aksesibilitas ke tapak yang tinggi, letak yang strategis dan berada di pusat kota, ketersediaan utilitas publik pada tapak, luas lahan yang mencukupi, eksisting tapak yang datar dan mudah untuk diolah, serta bebas dari polusi udara dan air.

\subsection{Analisis Pencapaian}

Pencapaian ke dalam bangunan harus mudah diakses, mudah dilihat dan memiliki sirkulasi yang aman akan menstimulus orang untuk masuk dalam area bangunan.

1. Tujuan: menentukan main entrance dan side entrance 
2. Dasar Pertimbangan: kemudahan akses, sirkulasi tapak yang aksesibel, arus kendaraan dan potensi jalan, tingkat keamanan.

3. Proses analisis

\section{Main Entrance (ME)}

Mudah dijangkau dan terlihat jelas. Menghadap langsung ke jalan utama untuk kemudahan sirkulasi kendaraan masuk dan ke luar tapak.

Side Entrance (SE)

Tidak mengganggu keberadaan ME. Membantu sirkulasi pengguna.

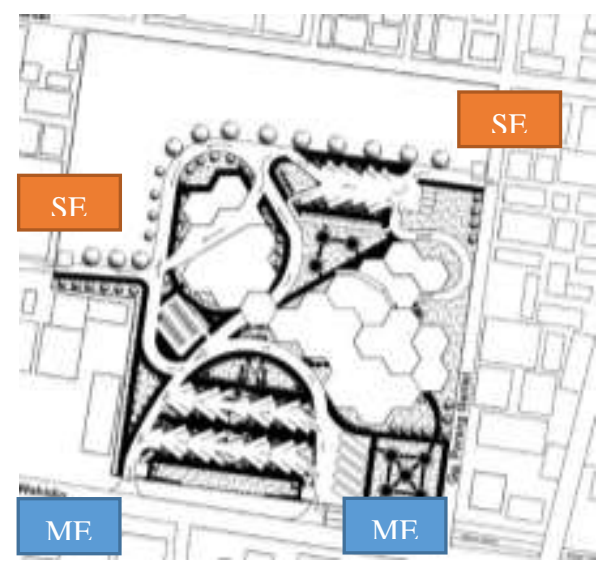

Gambar 1. Pola Pencapaian Tapak

Pada Gambar 1 terlihat pemisahan pola pencapaian untuk pengunjung dan pengelola museum

\subsection{Analisis Pemintakatan (Penzoningan)}

Pemintakatan berdasarkan sifat kegiatan dan keadaan dalam tapak dilakukan sebagai acuan dalam penataan peruangan, namun tetap memperhatikan modul-modul struktur yang telah diterapkan.

1. Tujuan: Menentukan mintakat (zoning) berdasarkan sifat kegiatan dan keadaan pada tapak.

2. Dasar pertimbangan: analisis peruangan, analisis pengolahan tapak, analisis struktur.

3. Proses analisis: persyaratan ruang, berdasarkan kelompok kegiatan dan analisis pengolahan tapak.

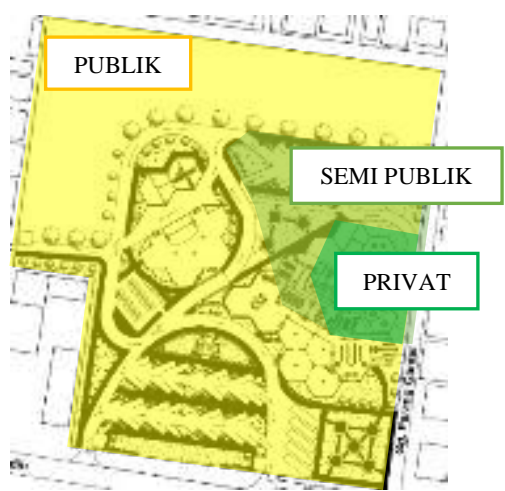

Gambar 2. Pemintakan pada Tapak (Horizontal)

Pada Gambar 2 terlihat pola pemintakan pada tapak di mana semakin membutuhkan privasi suatu kegiatan maka semakin ke dalam pemintakannya.

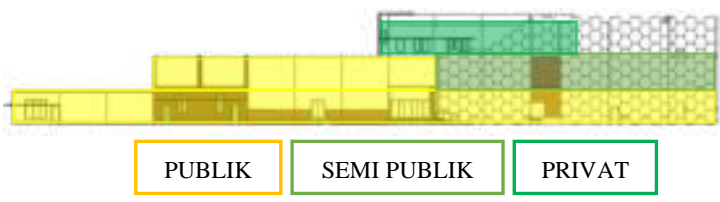

Gambar 3. Pemintakan pada Massa Bangunan (Vertikal)

Pada Gambar 3 terlihat pola pemintakan pada bangunan di mana semakin membutuhkan privasi suatu kegiatan maka semakin ke atas pemintakannya.

\subsection{Analisis Bentuk dan Tampilan \\ Bangunan}

\subsubsection{Analisis Bentuk Bangunan}

Tampilan bangunan museum yang direncanakan diolah dengan menggunakan unsur dari telekomunikasi seluler itu sendiri, baik secara bentuk massa maupun ornamentasi massanya.

Poin-poin pertimbangan yang digunakan pada pembentukan bentuk dasar bangunan adalah sebagai berikut:

1. Karakter bangunan.

2. Kondisi dan bentuk tapak.

3. Efisiensi dan fleksibilitas baik fungsi maupun peruangan.

4. Nilai estetika bangunan.

5. Pencerminan terhadap kegiatan yang ditampung.

6. Kemudahan sirkulasi dan pencapaian

Bentuk dasar massa bangunan dibentuk dari massa segienam yang diambil dari visualisasi seluler yang juga berbentuk sama, 
bentuk segienam tersebut digunakan sebagai modul ruang, modul segienam kemudian ditata menurut sifat dari kegiatan pada massa yang hendak diwadahi.

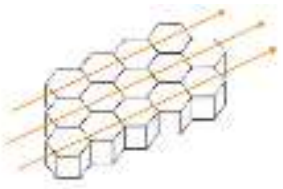

Gambar 4. Penataan Massa Bangunan Utama Lantai 1

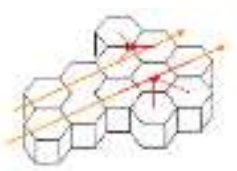

Gambar 5. Penataan Massa Bangunan Utama Lantai 2

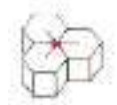

Gambar 6. Penataan Massa Bangunan Utama Lantai 3

Gambar 4,5 dan 6 adalah penataan massa bangunan utama yang terdiri dari tiga lantai, tiap lantai disusun secara berbeda sesuai dengan sifat dari kegiatan ditiap lantai tersebut:

1. Lantai 1 merupakan pusat kegiatan pameran yang bersifat publik/teratur sehingga massa ditata secara linier.

2. Lantai 2 memiliki kegiatan semi-publik dan publik sehingga massa ditata secara linier dan memusat pada titik-titik kegiatan semi publik.

3. Lantai 3 merupakan lantai khusus pengelolaan, di mana sifat kegiatan yang diwadahi bersifat privat/tertutup, sehingga penataannya secara memusat.

Selain bangunan utama terdapat bangunan pendukung lainnya seperti bangunan serbaguna dan bangunan servis yang ditata dari penataan memusat sebagai berikut:

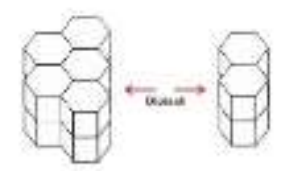

Gambar 7. Penataan Massa Bangunan Penunjang
Gambar 7 menunjukan pembentukan massa penunjang (massa kanan, serbaguna, massa kiri servis) yang didapat dari pemisahan penataan memusat yang menjadi pusat kegiatan pada bangunan penunjang.

Massa yang sudah ada ditata sesuai dengan kebutuhan ruang yang ada, terutama pada bangunan utama di mana massa ketiga lantai ditumpuk menjadi satu massa gabungan (Gambar 8), dan pemisahan massa servis menjadi satu tumpuk karena kebutuhan peruangan yang tidak besar pada massa servis (Gambar 9)

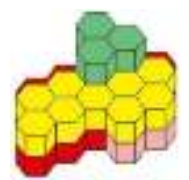

Gambar 8. Massa Gabungan Bangunan Utama

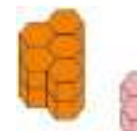

Gambar 9. Massa Gabungan Bangunan Pendukung

Massa gabungan kemudian ditata di tapak yang sudah ada dengan pemisah antar bangunan berupa ruang yang dibentuk pula seperti segienam agar kontinuitas penggunaan bentuk dasar segienam tetap terlihat dan massa keseluruhan menyerupai jaringan seluler seperti yang terlihat dalam Lampiran 1.

\subsubsection{Analisis Tampilan Bangunan}

Tampilan bangunan Museum Telekomunikasi Seluler dipusatkan pada penggunaan secondary skin yang mengadopsi bentuk massa bangunan pula.

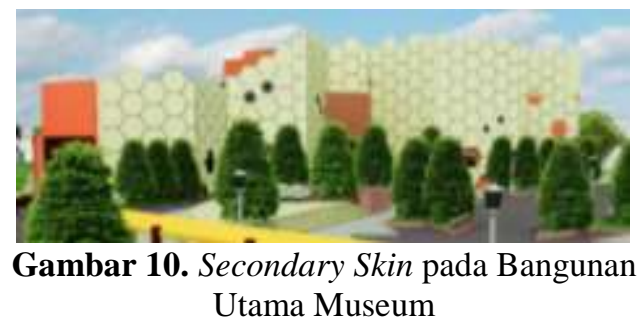

Pada Gambar 10 secondary skin yang digunakan menutupi hampir seluruh permukaan bangunan yang menghadap ke sisi barat, hal ini 
bertujuan selain untuk memberikan kesan monumental karena penggunaan yang menyeluruh pada bangunan, selain itu secondary skin ini juga bersifat fungsional karena menghalangi sinar matahari langsung yang dapat memberi panas berlebih ke dalam bangunan.

Secondary skin ini terbuat dari lembaran gypsum board dan fiberglass yang disangga pada rangka aluminium yang kemudian ditambatkan ke rangka bangunan dengan menggunakan baja ringan, penggunaan gypsum board dan fiberglass yang memiliki tekstur kasar ini bertujuan agar pemantulan cahaya matahari tersebar sehingga tidak menimbulkan silau.

\subsection{Analisa Penyimpanan dan Pameran Materi Koleksi Museum}

\subsubsection{Analisis penyimpanan materi koleksi} museum

Penyimpanan materi koleksi pada Museum Telekomunikasi Seluler yaitu sekitar 3180 unit materi koleksi yang dibagi menjadi tiga kategori yaitu:

1. Penyimpanan utama, sebesar 2720 unit

2. Penyimpanan karantina, sebesar 460 unit

3. Penyimpanan sementara sekitar 240 unit

Materi koleksi disimpan didalam lemari khusus kedap udara yang menjaga materi koleksi dari debu dan juga organisme yang dapat merusak, selain itu penyimpanan di dalam ruang dijaga dalam rentang tertentu yaitu:

1. Suhu :20-25 $\mathrm{C}$

2. Kelembaban : $45-60 \%$

3. Luminasi maks : 200 lux dari cahaya buatan (LED, TL, FL)

4. Bebas listrik statis

5. Bebas polusi udara

Kebutuhan akan suhu udara yang dibawah rata-rata suhu udara di Kota Surakarta berimbas dengan penggunaan pendingin udara yang dinyalakan selama 24 jam.

\subsubsection{Analisis pameran materi koleksi museum}

1. Periodisasi pameran Pameran pada Museum Telekomunikasi Seluler mengacu pada Pedoman Pendirian Museum (Direktorat Permuseuman, 1999/2000) di mana pameran dibagi menjadi dua jenis yaitu pameran tetap dan pameran sementara, pameran utama dibagi menjadi tujuh periode dengan tambahan satu pameran sementara menghasilkan delapan ruang pamer yang dibagi menjadi periode sebagai berikut:

a. Periode 0G (Periode Praanalog/Radio) jumlah 30 unit

b. Periode 1G (Periode Analog) jumlah 40 unit

c. Periode $2 \mathrm{G}$ era $90 \mathrm{an}$ (Periode Digital-Awal) jumlah 160 unit

d. Periode 2G era 2000 (Periode Multimedia) 400 unit

e. Periode 3G era 2000 (Periode Digital-Modern) 600 unit

f. Periode 3G era 2010 (Periode Ponsel Pintar) 400 unit

g. Periode 4G (Periode Broadband) 200 unit

Perangkat seluler yang tidak masuk kategori di atas menjadi koleksi pendukung dan ditempatkan pada pameran sementara yang dirotasi temanya setiap beberapa waktu

2. Sistem penyajian materi

Penyajian materi koleksi pada utamanya menggunakan bidang pamer yang dilindungi dengan kaca, terdapat empat sistem penyajian materi koleksi, yaitu:

a. Penyajian horizontal dengan ukuran dasar $1,2 \times 1 \mathrm{~m}$

b. Penyajian vertikal dengan ukuran dasar 2x0,6m

c. Penyajian bertingkat dengan ukuran dasar $0,6 \mathrm{x} 0,6 \mathrm{~m}$ dan $1,2 \times 1,2 \mathrm{~m}$

d. Penyajian interaktif dengan ukuran dasar 2x0,6m 


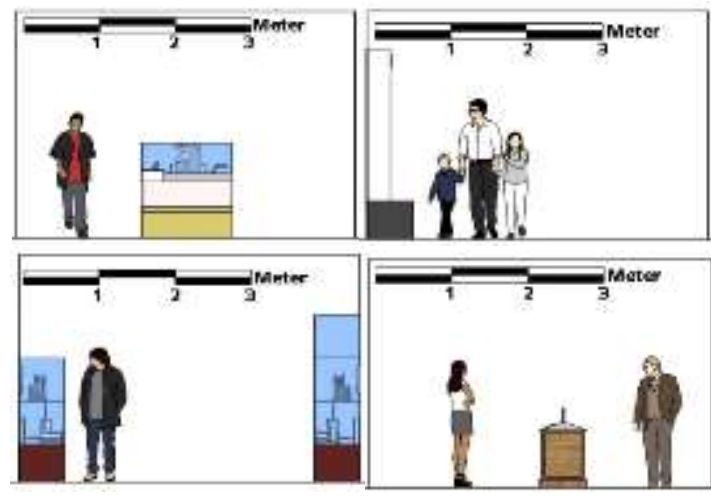

Gambar 11. Perbandingan Penyajian Materi Koleksi

Gambar 11 menunjukan perbandingan baik ukuran maupun jenis penyajian materi koleksi yang digunakan, bentuk dari bidang pamer tersendiri tidak terbatas dalam satu bentuk, asalkan masih dalam batas ukuran dasar yang telah ditetapkan.

3. Kenyamanan pandang

Kenyamanan pandang materi koleksi diperhitungkan dari dua bidang pandang nyaman manusia di mana manusia dapat mengamati satu benda secara keseluruhan tanpa harus menggerakkan bola matanya, yaitu sebesar $60-70^{\circ}$ vertikal dan $15-30^{\circ}$ horizontal (Buxton, 2015), sehingga jika diketahui besar rata-rata materi koleksi yaitu $19 \times 13 \mathrm{~cm}$ maka jarak pandang nyaman yang didapat sebesar $18-37 \mathrm{~cm}$.

\subsection{Analisis Struktur Bangunan}

Sistem struktur pada bangunan museum dibagi menjadi tiga yaitu sub structure, super structure, dan upper structure,

Kriteria pemilihan sistem struktur didasarkan sebagai berikut:

1. Kesesuaian jenis struktur dengan karakter bangunan

2. Kesesuaian struktur dengan bentuk dan tampilan bangunan

3. Kondisi tanah pada tapak yang terpilih.

4. Kemudahan pemasangan saat konstruksi.

5. Keawetan material.

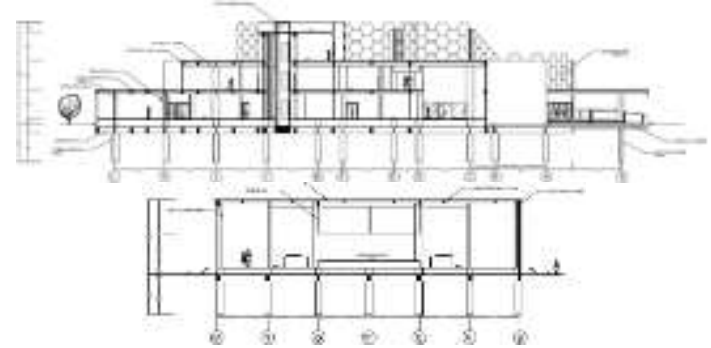

Gambar 12. Potongan Bangunan Utama dan Bangunan Serbaguna

Pada Gambar 12, sub structure yang digunakan pada massa bangunan utama dan bangunan serbaguna adalah pondasi sumuran dengan pertimbangan tinggi bangunan dan juga eksisting sekitar bangunan yang merupakan kawasan permukiman, di mana pelaksanaan pondasi sumuran yang tidak mengganggu masyarakat sekitar tetapi masih dapat menopang bangunan bertingkat, sedangkan bangunan servis seperti pada Gambar 13 yang terdiri dari satu tingkat menggunakan pondasi batu kali

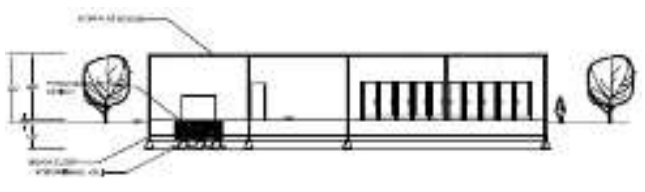

Gambar 13. Potongan Bangunan Servis

Sistem super structure bangunan museum menggunakan sistem rangka beton, sedangkan upper structure bangunan museum menggunakan sistem atap plat bondek, atap plat bondek merupakan jenis atap yang menggunakan beton bertulang seperti atap dak tetapi juga menggunakan plat khusus pada bagian bawah, atap yang dihasilkan plat bondek lebih murah dan lebih rapi daripada dak biasa, selain itu atap plat bondek lebih tahan api dengan kekuatan yang sama dengan atap dak biasa, plat yang digunakan dapat dilihat pada Gambar 14. 

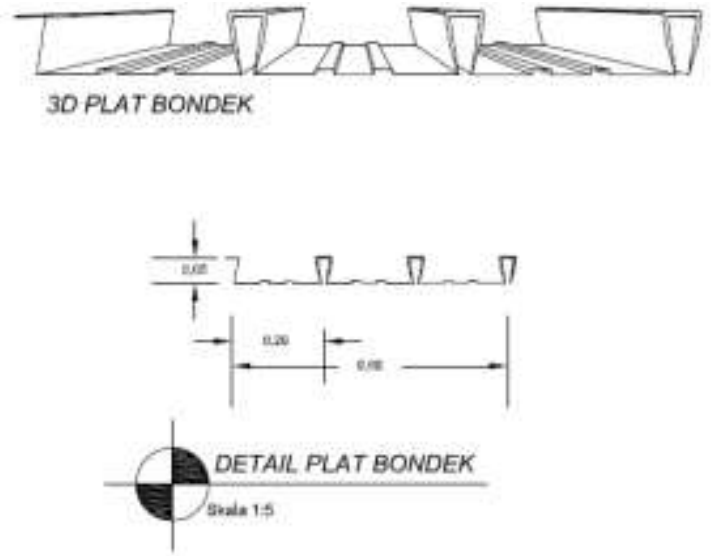

Gambar 13. Detail dan 3D Plat Bondek

\subsection{Analisis Sistem Pencahayaan dan Penanganan Kebakaran}

Sebagai bangunan museum, sistem utilitas yang dirasa paling penting dan memiliki fokus tersendiri sehingga layak untuk dipaparkan yaitu:

\subsubsection{Analisis sistem pencahayaan}

Sistem pencahayaan pada Museum Telekomunikasi Seluler, terutama pencahayaan buatan didasarkan oleh kriteria berikut ini:

1. Fungsi bangunan sebagai museum.

2. Materi koleksi museum.

3. Kenyamanan dan keamanan pengguna.

4. Bebas dari radiasi ultraviolet.

Pencahayaan buatan dimaksimalkan pada area pamer untuk memelihara materi koleksi dan menciptakan suasana yang sesuai dengan karakter perangkat seluler sebagai materi koleksi, di mana standar 50-200 lux dengan warna warm-neutral white (2500$4000^{\circ} \mathrm{K}$ ) optimal untuk pencahayaan pada ruang pamer, angka ini dapat dicapai dengan penggunaan lampu LED tanpa menimbulkan kerusakan pada materi koleksi.

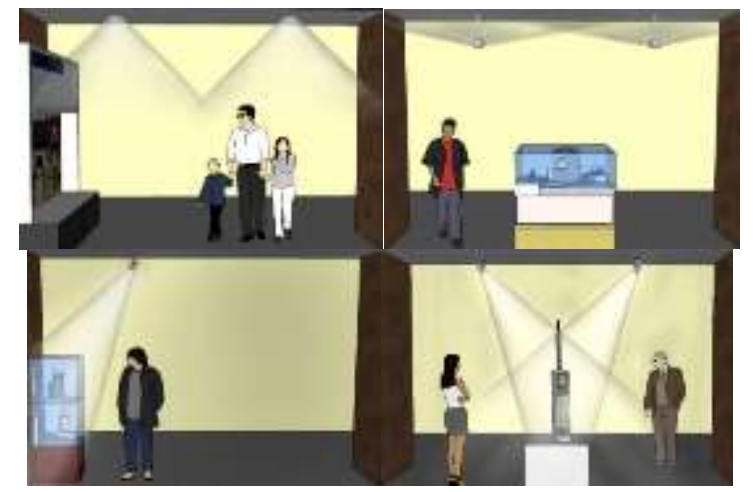

Gambar 14. Tipe Pencahayaan yang Digunakan pada Ruang Pamer
Pada Gambar 14 ditunjukkan tipe-tipe pencahayaan buatan yang digunakan, searah jarum jam dari pojok kiri atas yaitu:

1. Pencahayaan langsung yang bersifat monoton yang digunakan sebagai pencahayaan secara umum pada ruang pamer.

2. Pencahayaan tidak langsung yang bersifat lembut digunakan untuk pemberian efek suasana tenang.

3. Pencahayaan searah yang bersifat memberikan penekanan pada materi koleksi, dan

4. Pencahayaan dua arah yang menonjolkan benda, digunakan untuk penanda point of interest pada satu ruang pamer, misal model digunakan bersamaan dengan pencahayaan tidak langsung jika yang ditonjolkan adalah materi koleksi perangkat seluler agar tidak merusak.

\subsubsection{Analisis sistem penanganan kebakaran Kriteria:}

1. Fungsi bangunan sebagai museum

2. Materi koleksi museum

3. Kenyamanan dan keamanan pengguna

Sistem penanganan kebakaran pada museum utamanya menggunakan sistem sprinkler air dan gas, sistem air digunakan pada tempat-tempat umum yang tidak terdapat materi koleksi, sedangkan sistem gas digunakan pada titik-titik vital di mana sistem air dapat merusak koleksi seperti ruang penyimpanan, ruang arsip, ruang perpustakaan dan ruang pamer. Selain itu sistem penanganan kebakaran pada bangunan museum juga di bantu dengan alarm api/gas, fire extinguisher, indoor hydrant, dan outdoor hydrant.

\section{KESIMPULAN (KONSEP DESAIN)}

Konsep rancangan museum dengan fokus sebagai wadah penyimpanan, perawatan, penyajian, dan pendidikan perkembangan teknologi telekomunikasi seluler. Dari hasil analisa serta hasil korelasi dari beberapa data di atas, maka diperoleh hasil berupa rancangan Museum Telekomunikasi Seluler di Kota Surakarta sebagai berikut.

Nama Obyek : Museum Telekomunikasi Seluler Indonesia

Lokasi : Jl. Dr. Wahidin 
Luas Lahan $\quad: \pm 22.263,5 \mathrm{~m}^{2}$

Luas Bangunan : $\pm 9282,6424 \mathrm{~m}^{2}$

Daya Tampung : 300-400 orang

Kegiatan $\quad:$ museum dan pusat studi

Pengolahan peruangan pada Lampiran 2 dan 3 secara konsisten menggunakan unsur segi enam pada area publik lantai satu dan dua, sedangkan area yang tidak atau tidak terlalu nampak unsur segienamnya dapat diidentifikasi sebagai area privat/semi privat, sebagai contoh pada Lampiran 4 di mana lantai 3 bangunan berfungsi secara penuh sebagai area pengelola yang bersifat privat, tidak digunakan pengelolaan segi enam secara penuh pada peruangannya.

Sementara itu desain eksterior bangunan seperti yang terlihat pada Gambar 15 menunjukkan desain pengolahan tapak dan juga eksterior bangunan pada bagian depan (tampak barat), dan pada Gambar 16 menunjukkan desain pengolahan eksterior bangunan belakang museum (tampak timur).

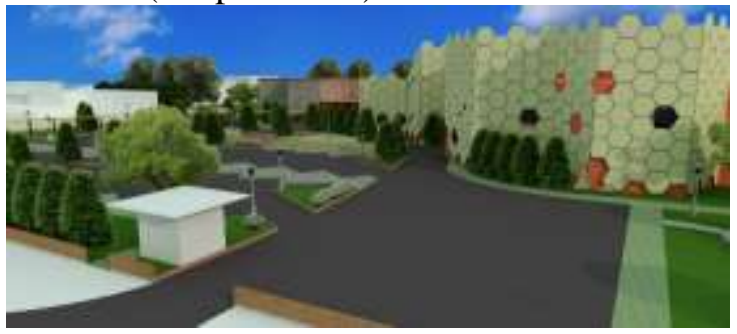

Gambar 15. Eksterior Bagian Barat

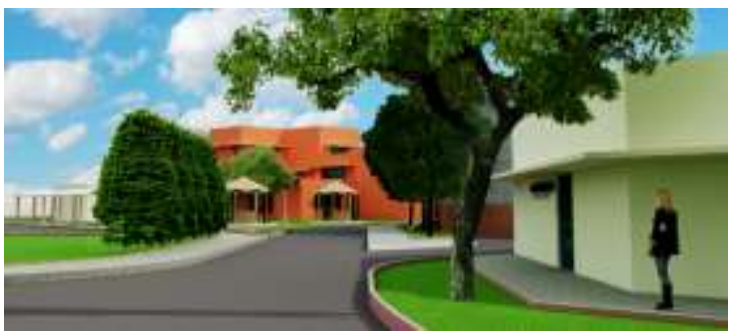

Gambar 16. Eksterior Bagian Timur

Sementara itu desain interior museum difokuskan sebagaimana ruang publik didesain, di mana terdapat penggunaan tanda-tanda yang jelas terutama tanda arah keluar dan juga ruang ruang utama seperti pada gambar lobby utama (Gambar 17 dan 18)

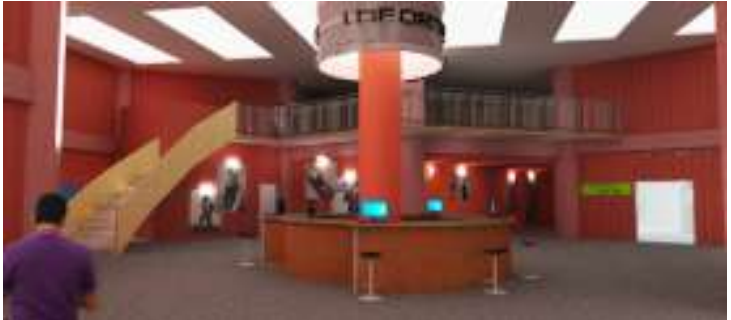

Gambar 17. Interior Ruang Lobby

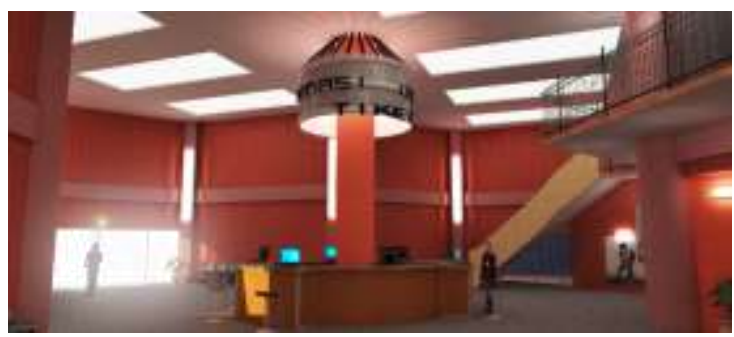

Gambar 18. Interior Ruang Lobby

Pada Gambar 19 ditunjukkan bagaimana ruang pamer ditata, di sini ruang pamer yang ditunjukkan adalah ruang pamer periode $0 \mathrm{G}$ di mana suasana ruang pamer dibuat satu tema dengan periodisasi materi koleksi, pada contoh ini karena ruang yang diwakili merupakan era sebelum dekade 1980an, maka penggunaan media foto hitam putih, panel kayu, wallpaper geometris berwarna cerah yang populer pada era sebelum 1980an memberikan suasana yang menyeluruh pada ruang pamer pertama.

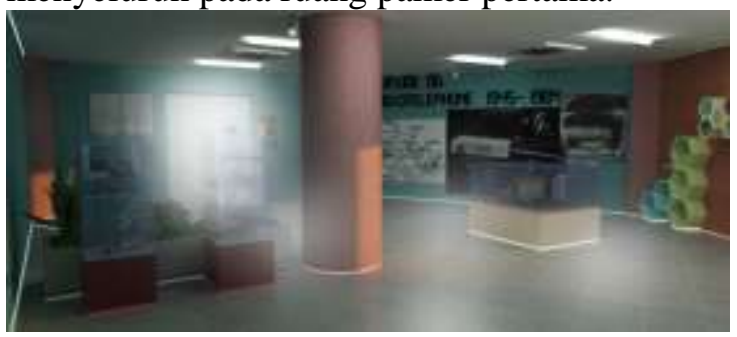

Gambar 19. Interior Ruang Pamer 1

\section{REFERENSI}

Direktorat permuseuman, 1999/2000, Pedoman Pendirian Museum.

Buxton, Pamela, 2015, Metric Handbook Planning and Design Data Fifth Edition.

PP No.19 tahun 1995

UU No.11 tahun 2010

http://data.un.org/Data.aspx?q=telephone\&d= ITU\& $\mathrm{f}=$ ind 1 Code $\% 3 \mathrm{a} 271$

http://www.e-cycle.com/tag/mobile-phonerecycling-statistics/ 

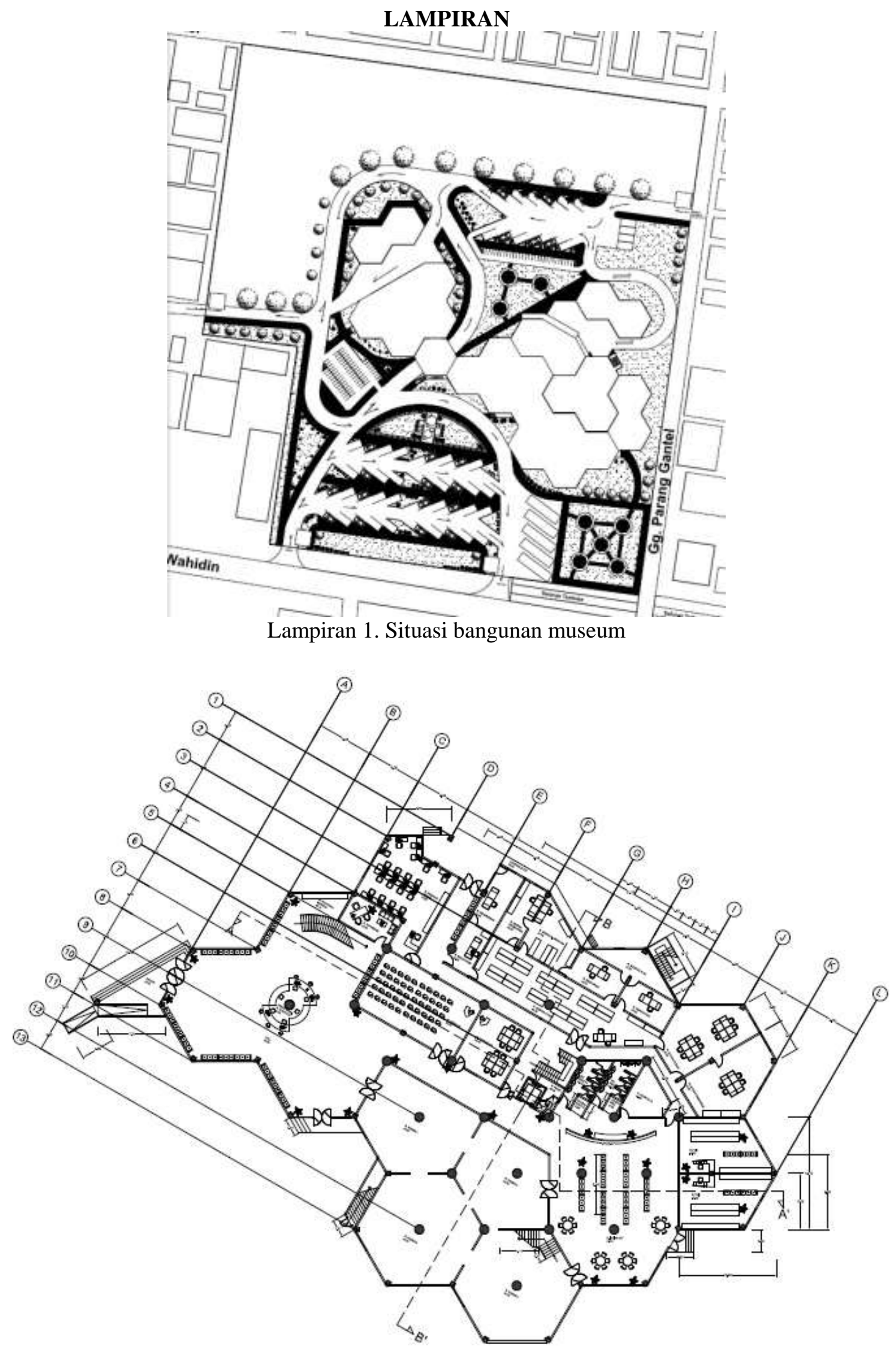

Lampiran 2. Denah lantai dasar bangunan utama museum 


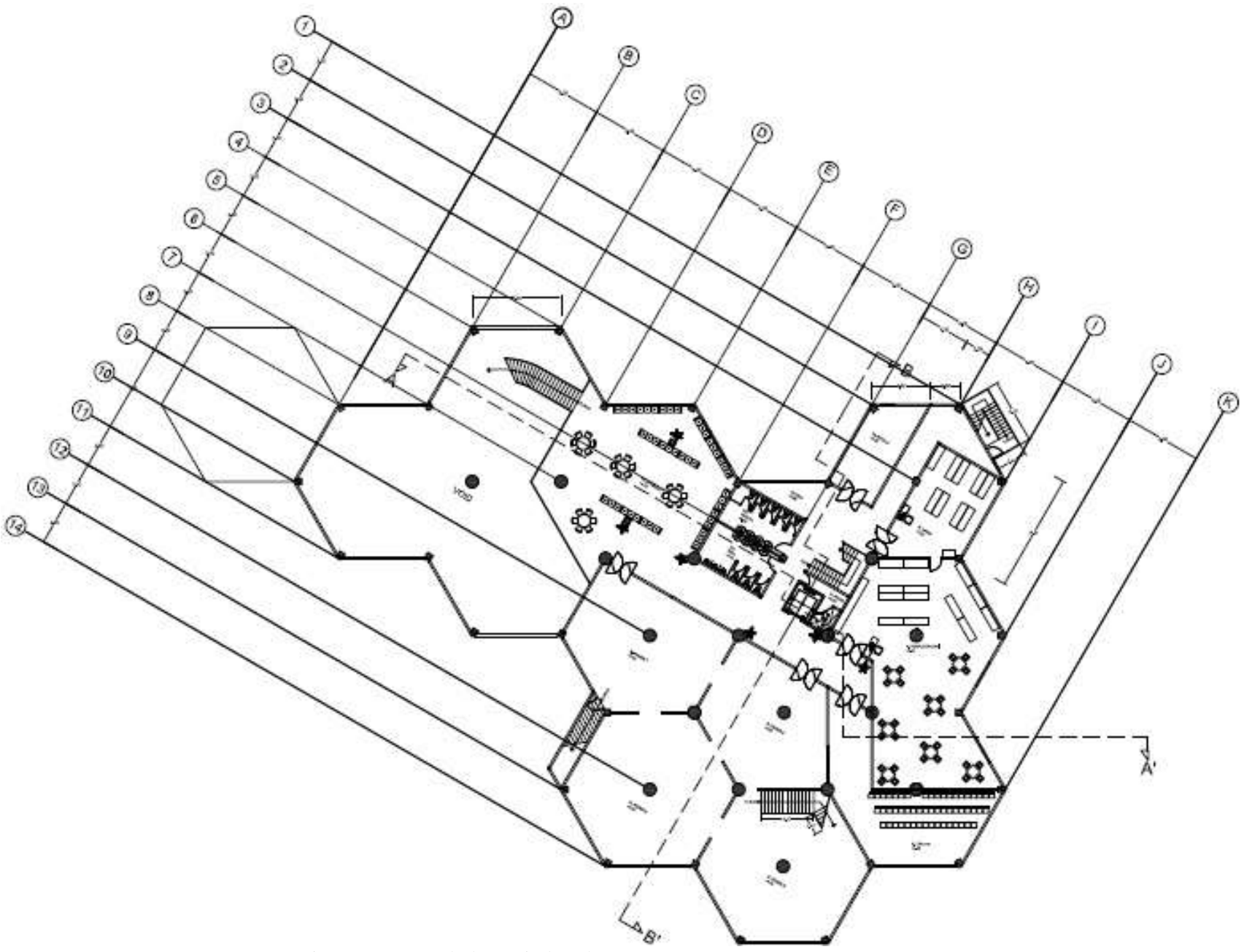

Lampiran 3. Denah lantai dua bangunan utama museum

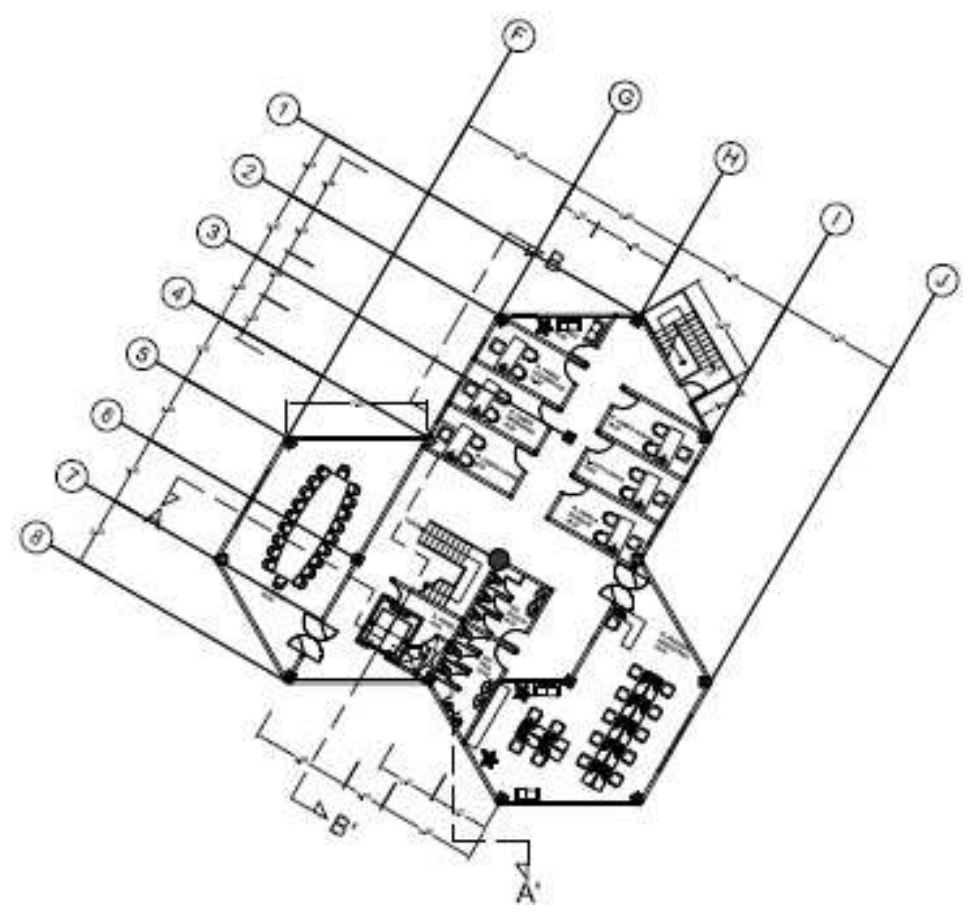

Lampiran 4. Denah lantai tiga bangunan utama museum 